\title{
IMEJ RUMPUT DALAM PERIBAHASA TAMIL: SUATU KAJIAN SEMANTIK INKUISITIF
}

\author{
Tangaprabu MURTHY, \\ Mary Fatimah SUBET ${ }^{2}$ \\ Fakulti Bahasa dan Komunikasi, \\ Universiti Malaysia Sarawak (UNIMAS), \\ 94300 Kota Samarahan, Sarawak, Malaysia. \\ $1_{\text {tangaprabu@gmail.com* }}^{*}$ \\ sufatimah@unimas.my
}

Manuscript received 25 February 2018

Manuscript accepted 21 June 2018

\begin{abstract}
ABSTRAK
Peribahasa Tamil merupakan cabang seni sastera lisan dalam budaya masyarakat India. Peribahasa juga dicipta hasil daripada pengamatan lapisan masyarakat terhadap keistimewaan alam semula jadi ciptaan Tuhan yang juga mempunyai makna tersurat dan tersirat. Sehubungan dengan itu, kajian ini bertujuan untuk mengenal pasti makna implisit di sebalik peribahasa Tamil yang menggunakan imej tumbuhan, khususnya imej rumput serta pengaruh budaya yang menyebabkan lahirnya peribahasa yang melibatkan imej tumbuhan di samping mengenali makna harfiah peribahasa Tamil yang menggunakan imej tumbuhan. Kajian ini bukan sahaja dilaksanakan untuk mengenal pasti dan menganalisis makna implisit di sebalik penggunaan 25 peribahasa Tamil yang menggunakan imej tumbuhan malah juga untuk menganalisis pengaruh budaya dan akal budi dari aspek semantik inkuisitif dalam peribahasa Tamil yang mempunyai imej tumbuhan. Di samping itu, kajian ini juga dilaksanakan mengikut kaedah kualitatif iaitu melalui temu bual terhadap empat orang informan dan ulasan yang dibuat terhadap peribahasa Tamil yang menggunakan imej tumbuhan. Dapatan kajian ini menunjukkan bahawa masyarakat India mencipta setiap peribahasa menggunakan alam semula jadi di sekeliling mereka. Selain itu, setiap peribahasa yang dicipta mempunyai makna implisit di sebaliknya dan setiap makna itu mempunyai satu ikatan yang kukuh dengan budaya serta akal budi masyarakat tersebut. Kesimpulannya, penelitian terhadap peribahasa Tamil telah menyerlahkan ketinggian pemikiran dan akal budi masyarakat India dalam penciptaan peribahasa Tamil yang menggunakan imej tumbuhan.
\end{abstract}

Kata kunci: peribahasa Tamil, semantik, semantik inkuisitif, imej tumbuhan, bahasa Tamil 


\title{
Grass Images in Ancient Tamil Proverbs: A Semantic Inquisitive Research
}

\begin{abstract}
Tamil proverbs are the art of spoken literature among the Indian community. These proverbs are created based on their contemplation towards the beauty and uniqueness of the nature and also their surroundings. They believed all these components of nature have something to tell, be it directly, indirectly or both. In conjunction with that, this study examined implicit meanings underlying the usage of Tamil proverbs related to nature; plants. This study also focused on how culture affects the creation of the Tamil proverbs related to plants to provide literal understanding to a proverb. This study also analysed inquisitive meanings in order to provide a better understanding about Tamil proverbs. Since this is a qualitative study, four informants were interviewed to obtain the data. The results showed that the proverbs on plants that exist are created from the surroundings of the native Tamils. Every proverb from the previous people has a strong cognitive connection with implicit meanings where they convey messages figuratively. This study portrays high order of thinking skills among the Indian community which establishes their way of cognition about plants.
\end{abstract}

Keywords: Tamil proverbs, semantics, inquisitive semantics, plant images, Tamil language

\section{Pengenalan}

Menurut Ahmad (1965), "peribahasa ialah segala susunan cakap yang pendek yang telah melekat di mulut orang ramai sejak beberapa lama oleh sebab sedap dan bijak perkataannya, luas dan benar tujuannya dan dipakai akan dia jadi sebutan-sebutan oleh orang sebagai bandingan, teladan, dan pengajaran" (hlm. 165). Di samping itu, Zahid (1998) juga menyatakan idea yang hampir sama dengan Ahmad (1965) iaitu, penggunaan peribahasa ini sebenarnya mempunyai fungsi yang sangat menarik. Peribahasa digunakan dengan tujuan untuk menyampaikan maksud yang tertentu dengan cara yang cukup halus atau berlapik. Perkara yang dinyatakan oleh Zahid (1998), benar kerana pada masa dahulu masyarakat tidak suka menyinggung perasaan seseorang begitu sahaja. Mereka lebih gemar menggunakan bahasabahasa kiasan ibarat, seperti bahasa kiasan, peribahasa, simpulan bahasa dan sebagainya. Peribahasa sebenarnya mempunyai pelbagai fungsi. Tamsilnya, peribahasa digunakan sebagai peringatan, nasihat dan kritikan untuk tujuan kebaikan kepada seseorang. Penggunaan peribahasa berupaya membawa mesej yang bersifat nasihat tanpa menyinggung hati dan perasaan seseorang. Selain itu, penggunaannya mempunyai matlamat yang tersendiri, iaitu agar orang yang mendengar atau membacanya tidak mudah rasa tersinggung dalam sesebuah komunikasi. Menurut Abdullah (1997), “peribahasa merupakan satu daripada cabang sastera lama, bukan sahaja bagi bangsa Melayu tetapi juga bagi hampir semua bangsa di dunia" (hlm. xi). 
Bahasa merupakan satu identiti sesebuah masyarakat. Bahasa Tamil merupakan satu lambang identiti bangsa India. Asal usul bermula di negara India. Tamil merupakan satu bahasa klasik dan salah sebuah bahasa yang tergolong dalam rumpun Bahasa Dravida. Selain itu, Bahasa Tamil ini ditutur oleh bangsa India di Tamil Nadu (India Selatan), Sri Lanka, bangsa India di Malaysia, Singapura, Australia, Canada dan sebagainya. Sementara itu, bahasa Tamil ini dituturkan seramai lebih kurang 74 juta penutur di seluruh dunia. Justeru, memang tidak dapat disangkal bahawa bahawa Tamil ini mempunyai tradisi literasi yang berterusan tanpa sekatan untuk jangka waktu ruang lama jika dibandingkan dengan bahasa-bahasa lain di dunia secara amnya serta dalam rumpun bahasa Dravidia secara khasnya. Malah terdapat juga beberapa penemuan penulisan-penulisan awal bahasa Tamil ini. Antaranya ialah, penulisan pada Batu Bersurat yang menunjukkan bahawa batu itu telah dihasilkan pada kurun ke-3 sebelum masihi (Nayak, 2002). Dalam pada itu, bahasa Tamil dianggap sebagai salah satu bahasa yang paling tua selepas bahasa Latin. Bahasa Tamil ini juga mempunyai budaya kesusasteraan serta unsur tatabahasa yang lengkap. Malah, teks terawal bahasa Tamil ditemui bertajuk "Tolkappiyam" yang menceritakan serta mencerminkan tatabahasa Tamil yang klasik tahun 500 masihi. Teks yang ditemui itu adalah dalam bentuk puisi. Selain itu, terdapat manuskrip lain yang ditemui iaitu "Purananuru" yang ditulis dalam kelopak (daun palma) yang juga ditulis dalam bahasa Tamil. Manuskrip ini pula berbentuk puisi dan isinya pula menceritakan budaya masyarakat Tamil, adat resam, kisah pemerintah (maharaja), kehidupan masyarakat biasa, cinta terhadap manusia dan juga tumbuhan pada zaman tersebut (Yokammal, 2008). Pada waktu yang sama, tulisan Tamil mengalami perubahan dari segi bentuknya. Pada masa dahulu masyarakat menggunakan bahasa Tamil purba manakala kini tulisan tersebut mengalami transformasi sehingga menjadi tulisan yang "standard".

Darsawarsa ini, bahasa Tamil merupakan bahasa rasmi beberapa buah kerajaan seperti Tamil Nadu, India, Sri Lanka dan juga Singapura serta diiktiraf di negara Afrika Selatan. Bahasa Tamil dituturkan di pelbagai negara dan merupakan satu bahasa yang kukuh sehingga kini. Jika dilihat dari perseptif yang berbeza, masyarakat India juga maju dari segi teknologi. Contohnya, pada masa kini pelbagai negara berlumba-lumba untuk mendapatkan teknologi nuklear. Walakin begitu, masyarakat India sudah lama mencipta teknologi berupa nuklear. Hal ini benar seperti yang terdapat dalam kitab masyarakat India iaitu "Bhagavad Gita".

Masyarakat India dibawa masuk ke Tanah Melayu oleh pihak Inggeris kerana ketandusan tenaga buruh dalam pelbagai sektor seperti pembinaan jalan raya dan landasan kereta api, sektor perladangan getah dan tebu serta sektor perkhidmatan awam kerajaan. Hal ini disebabkan upah buruh India murah jika dibandingkan dengan buruh dari negara lain. Lebih-lebih lagi, apabila mereka mula-mula dibawa masuk, buruh India hanya berkerja di ladang-ladang getah tetapi sekarang mereka bekerja di semua sektor. Kedatangan mereka bertambah pada awal abad ke-20. Sebelum itu orang India yang datang hanya terdiri daripada para pedagang sahaja. Pada tahun 1820-an, setelah menandatangani perjanjian Inggeris-Belanda (1824), pihak Inggeris berundur ke Sumatera. Impaknya, ramai banduan bangsa India dipindahkan ke negeri-negeri Selat dari Bengkulim. Setelah itu, pada tahun 1840-an, sejurus ladang-ladang baharu di Seberang Prai dibuka, lebih ramai buruh India mula 
diimport. Jumlah buruh bertambah selepas tahun 1880-an hasil daripada pembukaan lebih banyak ladang tebu serta getah. Kebanyakan mereka tinggal di negeri-negeri Perak, Kedah, Selangor, Johor, Negeri Sembilan dan sebagainya iaitu di mana-mana terdapatnya penanaman getah yang diusahakan dalam skala besar. Mengikut Jabatan Perangkaan Malaysia (2013), berdasarkan tinjauan yang dilakukan pada tahun 2012, jumlah penduduk India di Malaysia adalah sebanyak 1.9 juta iaitu $6.7 \%$ daripada rakyat Malaysia. Hal ini membuktikan bahawa bahasa Tamil masih wujud dan dipertuturkan di negara kita dan juga mempunyai pengaruh yang kuat dari segi sosial, politik, dan ekonomi Malaysia.Oleh yang demikian, kajian ini berpendapat bahawa masyarakat India yang maju dari segi bahasa, nilai budaya malah teknologi juga memiliki peribahasa mereka tersendiri. Hal ini dapat dibuktikan melalui hasil-hasil penemuan manuskrip lama. Kajian ini berpendapat, jika seseorang itu mampu menulis manuskrip, sudah semestinya mereka juga dapat menghasilkan peribahasa, simpulan bahasa, kiasan berdasarkan pengalaman mereka itu. Oleh hal yang demikian kajian ini bertujuan untuk mengenal pasti makna implisit di sebalik peribahasa Tamil yang menggunakan imej rumput serta pengaruh budaya yang menyebabkan lahirnya peribahasa yang melibatkan imej rumput di samping mengenali maka harfiah peribahasa Tamil yang menggunakan imej rumput. Manakala objektif kajian ini pula ialah mengenal pasti peribahasa Tamil yang mengandungi imej rumput dan menganalisis makna implisit di sebalik penggunaan peribahasa Tamil berunsurkan imej rumput dengan mengaplikasikan pendekatan semantik inkuisitif serta menghuraikan pengaruh budaya, falsafah dan akal budi dalam peribahasa Tamil yang mengandungi imej rumput ini.

\section{Tinjauan Literatur}

Penggunaan peribahasa pula merupakan satu kepelbagaian dalam sesuatu bahasa. Tujuan utama sesuatu peribahasa adalah untuk menyampaikan mesej dengan merujuk lambang yang mempunyai fungsi yang sama atau hampir sama dengan cara pemikiran yang hendak disampaikan oleh seseorang. Lambang tersebut dipetik daripada persekitaran sekeliling manusia supaya mudah dikaitkan. Hal ini selari dengan pandangan tokoh bahasa iaitu Omar (1993) yang mengatakan bahawa peribahasa merupakan hasil daripada tanggapan masyarakat terhadap persekitaran dan juga hasil pemahaman mereka terhadap alam nyata. Lambang bahasa ini dijadikan sebagai medium untuk merakam pengalaman dan fikiran mereka.

Kajian yang berkaitan peribahasa Tamil agak terbatas dan tidak sepenuhnya menumpukan kepada peribahasa bahasa Tamil semata-mata tetapi membandingkan peribahasa yang terdapat dalam bahasa lain. Contohnya dalam kajian Ragavan dan Salleh (2015) penyelidik hanya membandingkan peribahasa Melayu dan peribahasa Tamil untuk menampakkan persamaan serta perbezaan antara kedua-dua bahasa dalam aspek sosial. Persamaan itu dilihat melalui tiga aspek sosial iaitu aspek tingkah laku, pemikiran, serta nilai murni. Semua peribahasa yang dipilih mempunyai makna yang hampir sama dalam kedua-dua bahasa. Malah dalam kajian tersebut juga, penyelidik berpendapat bahawa peribahasa itu lahir daripada pengamatan fenomena alam serta mengaitkannya mengikut teori Sapir (1921) yang membawa kepada hubungan antara bahasa, budaya, dan pemikiran. Peribahasa yang berkaitan 
dengan tingkah laku, pemikiran dan nilai murni dipilih serta melihat persamaannya dalam dua bahasa tersebut. Hal ini membantu penyelidik untuk mengetahui informasi-informasi yang berkaitan dengan peribahasa serta dapat melihat cara pemikiran orang dahulu kala. Kajian ini membuktikan bahawa peranan utama penggunaan peribahasa adalah untuk menyampaikan sesuatu perkara dengan merujuk lambang yang mempunyai fungsi dan penggunaan yang sama dengan pemikiran atau nilai yang hendak disampaikan.

Selain daripada itu, mengikut Hamzah dan Mat Hassan (2011) mengaitkan pemikiran dalam peribahasa dengan konsep hipotesis Sapir (1921). Malah bahasa dikatakan mempunyai hubungan yang intrinsik antara sikap, pemikiran, dan perilaku seseorang dalam sesuatu bangsa dan hal ini boleh dilihat dan diidentifikasikan melalui penggunaan bahasa tersebut termasuk peribahasa. Bahasa juga mempunyai hubungan dengan kepercayaan serta nilai hidup dalam kebudayaan sesorang individu. Perlakuan seseorang mendorong membina kejelasan terhadap alam sekeliling lalu diungkapkan melalui bahasa. Walau bagaimanapun, penyelidik hanya mengkaji peribahasa Melayu sahaja. Namun demikian, kajian itu amat berguna untuk penyelidik untuk mengkaji cara pemikiran orang Melayu. Hal ini dapat dibuktikan melalui dapatan dalam kajian tersebut yang menyatakan bahawa dapatan kajian tersebut sejajar dengan pendapat Sapir (1921) iaitu bahasa menentukan pemikiran penutur. Kajian tersebut lebih mementingkan cara pemikiran seseorang yang juga dikaitkan dengan tingkah laku serta moral manusia. Kajian ini berpaksikan contoh-contoh daripada bahasa Melayu tetapi setiap peribahasa itu mempunyai kaitan dengan flora, fauna, kegiatan manusia, serta pemikiran malah tidak memfokuskan kepada semantik inkuisitif sebaliknya kajian tersebut menjurus kepada hipotesis Sapir (1921) sahaja.

Selain itu, ada kajian-kajian semantik inkuisitif juga pernah dilakukan seperti Jalaluddin (2014a, 2014b, 2015), Zakaria dan Jalaluddin (2015), Kasdan dan Jalaluddin (2015), Wan Mansor \& Jalaluddin $(2015,2016)$, Kasdan, Jalaluddin \& Wan Ismail (2016), Murthy (2017), Daud (2017, 2018a, 2018b) serta Daud dan Subet (2018). Mengambil contoh daripada kajian yang dilakukan oleh Kasdan, Jalaluddin dan Wan Ismail (2016), menggunakan imej haiwan iaitu ikan dalam kajian tersebut. Penyelidik mengkaji peribahasa yang mempunyai imej ikan tersebut dan dilihat dari aspek semantik inkuisitif serta menjelaskan maksud semantik inkuisitif. Gagasan utama dalam semantik inkuisitif ini adalah untuk meneroka makna ujaran orang Melayu tanpa meninggalkan falsafah dan akal budi Melayu. Penyelidik juga menjelaskan bahawa semantik inkuisitif ini bukan sahaja mencerminkan fenomena bahasa pada peringkat kognitif sahaja, malah lebih menumpukan kepada penerokaan bidang falsafah. Hal ini sejajar dengan pandangan Ciardelli, Groenendijk, dan Roelofsen (2012) yang menyatakan bahawa perasaan ingin tahu atau inkuisitif seseorang manusia menyebabkan sesuatu pengetahuan itu berkembang. Dapatan kajian ini membuktikan bahawa imej ikan itu dikaitkan dengan sikap orang Melayu. Hal ini disebabkan orang Melayu selalu dilabelkan sebagai orang yang malas namun perkara itu tidak benar sama sekali. Perkara ini dapat dijelaskan 
melalui penggunaan peribahasa yang kian lama wujud dalam masyarakat Melayu. Tamsilnya dalam peribahasa yang digunakan dalam kajian ialah "ikan biar dapat, serampang jangan pokah" yang nyata menunjukkan orang Melayu ingin mengingatkan agar kita harus berhati-hati serta teliti dalam melakukan sesuatu pekerjaan. Di samping itu, apabila melihat dapatan ini dari segi akal budi serta falsafah, imej ikan itu digunakan kerana mempunyai pelbagai kebaikan. Ikan-ikan yang terdapat di dalam paya, sungai atau kawasan yang berair memiliki sumber protein yang paling penting dan murah. Hal ini tidak bermakna protein daripada haiwan lain tidak penting tetapi makanan tersebut termasuk sebagai makanan mewah dan dikhususkan untuk perayaan tertentu sahaja. Namun demikian, hal itu bukanlah suatu yang utama, sebaliknya mempunyai ciri-ciri lain yang menyebabkan orang Melayu memilih imej ikan dalam peribahasa mereka. Kelebihan ikan turut disebutkan dalam al-Quran, surah al-Ma'idah, ayat 96:Dihalalkan bagimu haiwan buruan laut dan makanan yang berasal dari laut sebagai makanan yang lazat bagimu, dan bagi orang yang dalam perjalanan; dan diharamkan atasmu binatang buruan darat, selama kamu dalam ihram. Dan bertaqwalah kepada Allah, yang kepadanya kamu akan dikumpulkan.

al-Quran, surah al-Ma'idah,ayat 96

Perakuan Allah SWT tentang ikan di dalam al-Quran membuktikan bahawa makanan yang bersumberkan ikan sangat istimewa serta memberi khasiat yang baik untuk kesihatan. Oleh hal yang demikian orang Melayu dahulu memilih imej ikan untuk diselitkan dalam peribahasa Melayu. Kajian yang dilakukan ini hanya bertujuan untuk melihat makna di sebalik makna tersirat peribahasa Melayu yang menggunakan unsur ikan serta menghuraikan ilmu falsafah dan akal budi melayu tentang ikan itu yang dilihat melalui kaca mata semantik inkuisitif. Jika dilihat kajian Wan Mansor dan Jalaluddin (2016), juga menumpukan kepada bidang semantik inkuisitif tetapi kajian ini mengambil data bahasa kiasan yang merangkumi peribahasa, perumpamaan, simpulan bahasa yang menjadi sebahagian daripada penggunaan dalam cara hidup masyarakat Melayu. Kajian ini dilakukan bagi tujuan menghuraikan makna-makna implisit di sebalik penggunaan kiasan Melayu dengan akal budi Melayu. Kaedah yang digunakan dalam kajian ini bersifat kualitatif. Data yang digunakan merupakan hasil yang dikumpul dari tiga buah kamus serta dikukuhkan lagi dengan data korpus. Kaedah inkuisitif diaplikasikan dalam kajian ini yang menggabungkan data, teori, kognitif dan falsafah yang membawa kepada tafsiran akal budi Melayu. Penelitian diberi dalam pemilihan peribahasa-peribahasa Melayu yang berunsurkan deria rasa dan asosiasinya serta melihatnya dari segi semantik inkuisitif. Contohnya, kiasan seperti "sepahit-pahit mambu, kelatnya menjadi ubat", "pahit di luar, manis di dalam", "pahit getir kehidupan", "pahit meninggal", "pahit penghidupan", dan "kopi pahit". Jika dilihat pada kiasan yang pertama iaitu "sepahit-pahit mambu, kelatnya menjadi ubat" merujuk kepada nasihat yang boleh menyebabkan terasa atau kecil hati malah membawa manfaat yang amat positif namun kenapa mambu dikaitkan dengan sesuatu yang positif. Pokok semambu yang juga dikenali sebagai mambu ini ialah sebatang pokok hijau 
yang berdaun lebat. Keistimewaan pokok ini ialah setiap daun serupa atau menyamai daun yang matang. Batang pokok tersebut bertonik pahit dan beransangan. Pokok tersebut tumbuh dan hidup di negara yang beriklim tropika dan separa tropika. Pokok tersebut bersinonim sebagai pokok perubatan terutamanya dalam kalangan orang India. Kaum India menanam pokok mambu berhampiran kuil untuk digunakan dalam upacara keagamaan Hindu serta untuk kegunaan perubatan tradisional secara meluas. Dapatan menunjukkan bahawa perkataan "mambu" itu digunakan kerana ciri-ciri pokok mambu tersebut. Pokok tersebut rasanya pahit dan buahnya dikatakan beracun tetapi masih dianggap sesuatu yang bernilai. Masyarakat Melayu memilih objek mambu untuk disamakan dengan nasihat yang pedas tetapi mendatangkan faedah. Hal ini benar kerana apabila melihat dari segi pemakanan, bunga pokok mambu ini dimasukkan ke dalam masakan kari dan dijadikan sayur di India, Myanmar dan Vietnam (Farndon, 2011). Jika dilihat dari segi asosiasi deria rasa pula, penelitian dilakukan terhadap data peribahasa yang mengungkapkan kata yang berasosiasi dengan manis dan masin. Contohnya, kajian Jalaluddin (2014a) tentang peribahasa "menanam tebu di bibir mulut" Kenapa tebu dan bibir digunakan sebagai objek untuk menggambarkan sifat negatif? Tebu ini merupakan satu tanaman yang ditanam khususnya untuk pembuatan gula dan tebu juga dapat dimakan begitu sahaja dan memiliki rasa yang sangat manis. Tebu dapat mengeluarkan air yang manis dan berwarna hijau manakala bibir pula adalah salah satu anggota yang ada pada manusia dan digunakan untuk bercakap. Orang Melayu mengaitkan tebu yang manis itu untuk menggambarkan kata-kata yang manis yang dikeluarkan daripada mulut seseorang manusia. Jika dilihat dengan teliti, tebu secara alamiahnya rasanya sedap dan manis manakala bibir adalah alat artikulasi yang sangat berguna untuk bertutur. Namun demikian, masyarakat Melayu mengaitkannya dengan sikap negatif. Hal ini disebabkan struktur tebu itu. Tebu mempunyai daun yang tajam, kasap dan miang, kulit yang keras dan liat (Jalaluddin, 2014a). Tambahan pula, tebu mempunyai ruas-ruas yang keras namun begitu menghasilkan air yang manis dan enak rasanya. Oleh itu, masyarakat Melayu mengaitkannya dengan janji-janji yang ditaburkan, manis didengar dan enak untuk ditelan tetapi ciri janji itu mempunyai ciri- ciri yang sama seperti tebu iaitu keras, tajam, miang dan liat. Orang Melayu memberi gambaran terhadap sifat sesetengah manusia yang tidak berpegang kepada janji dan hanya mengeluarkan kata-kata yang baik serta manis tetapi mempunyai muslihat yang tersendiri seperti yang dikaitkan dengan objek tebu.

Apabila melihat peribahasa Melayu yang berasosiasi dengan deria masin pula, Jalaluddin (2014b) pula menggunakan peribahasa "banyak makan garam" sebagai data. Peribahasa tersebut merujuk kepada sesuatu yang pernah dialami atau dirasai oleh seseorang individu. Persoalan di sini ialah kenapa garam itu digunakan? Garam merupakan bahan pepejal yang berwarna putih dan masin rasanya, yang diperoleh daripada air laut atau dari dalam tanah dan mempunyai pelbagai kegunaan (termasuk sebagai perasa dan pengawet makanan, natrium klorida). Menurut pengkaji lagi, garam juga penting bagi kehidupan masyarakat sejak zaman dahulu lagi. Garam ini merupakan salah satu berkat yang paling awal diturunkan di bumi. Orang yang terawal pada zaman dahulu merasa garam kerana dalam kehidupan seharian, garam digunakan dalam pemakanan sebagai bahan perasa. 
Pengalaman seseorang juga melibatkan jangka masa yang merangkumi perkara yang pernah dialami atau dirasai oleh seseorang. Apabila membandingkan garam dan pengalaman, kedua-dua ini mempunyai persamaan iaitu jangka waktu yang lama. Oleh hal yang demikian, garam ini dikaitkan dengan pengalaman atau perkara yang pernah dirasai oleh seseorang. Hasil kajian menunjukkan bahawa setiap ciptaan kiasan itu mempunyai makna yang tersurat dan tersirat serta mempunyai kaitan dengan falsafah, kognisi dan akal budi itu sendiri sehingga boleh mencipta sesuatu dengan hanya menggunakan unsur alam. Hal ini disebabkan pada masa dahulu, kebanyakan masyarakat bekerja sebagai petani, nelayan, pelayar, memburu binatang, saudagar, pengembara dan sebagainya yang memungkinkan golongan ini menimba pengalaman serta pendidikan alam dan seterusnya diaplikasikannya dalam bahasa melalui penciptaan kiasan-kiasan dalam pelbagai bentuk dan mempunyai makna di sebaliknya agar tidak menyakitkan hati seseorang. Malah dalam kajian ini ketersiratan makna serta falsafah itu juga dilihat di sebalik peringkat akal budi. Melalui pembacaan kajian ini, penyelidik dapat merumuskan bahawa, kiasan Melayu mempunyai kaitan yang rapat dengan budaya dan akal budi Melayu serta dapat membuktikan hubungan bahasa, masyarakat, pekerjaan dan pemikiran.

Zakaria dan Jalaluddin (2016) juga menggunakan pendekatan semantik inkuisitif dalam kajian mereka yang bertajuk konsep ruang dalam anggun cik tunggal. Kajian ini bertujuan menganalisis ungkapan tersirat dalam Cerita Anggun Cik Tunggal yang menyingkap konsep ruang fizikal. Kaedah analisis pula lebih kepada pendekatan semantik inkuisitif yang menggabungkan teori, data, kognitif, falsafah serta akal budi masyarakat Melayu. Malah teori relevans juga digunakan sebagai satu cara mengkaji makna dalam cerita tersebut serta kaedah analisis mempunyai beberapa tahap. Pada tahap pertama penyelidik menggunakan teori relevans untuk mendapatkan makna manakala pada tahap kedua, penyelidik menganalisis lebih kepada kognitif dan pada tahap ketiga barulah penyelidk menganalisis menggunakan pendekatan inkuisitif. Penyelidik mendapati bahawa masyarakat dahulu mempunyai keakraban yang luar biasa dengan alam. Hal ini demikian kerana kebanyakan perkataan yang digunakan dalam cerita itu berunsur flora dan fauna. Masyarakat Melayu begitu bijak menggunakan unsur-unsur alam dalam peribahasa untuk mendidik masyarakat.

\section{Metodologi Kajian}

Penyelidik menggunakan kaedah yang bersifat kualitatif. Penyelidik menggunakan kaedah premier iaitu melalui temu bual. Penyelidik menemu bual seramai empat orang yang beragama Hindu dan mempunyai pendidikan bahasa Tamil. Pendidikan bahasa Tamil di sini bermaksud seseorang yang mampu menulis, membaca dan dapat bertutur bahasa Tamil dengan fasih. Salah seorang informan merupakan orang tua yang berumur dalam lingkungan 80 tahun dan tiga orang lagi merupakan orang yang berpendidikan tinggi. Tiga orang tersebut merupakan guru di sebuah sekolah Tamil. Penyelidik membuat keputusan untuk memilih seorang orang tua dan tiga orang yang berpendidikan tinggi kerana untuk membezakan nilai kefahaman mereka terhadap peribahasa Tamil yang menggunakan imej tumbuhan serta mendapat data yang sahih. Seramai tiga orang informan itu dipilih mengikut norma manakala 
seorang lagi dipilih secara rawak mengikut taraf pendidikan dan pengetahuan dalam bahasa Tamil. Hal ini dapat memudahkan penyelidik melakukan temu bual kerana jika mengikut norma sepenuhnya, penyelidik akan menghadapi kekangan dalam mentafsir data kerana bukan semua informan yang dipilih melalui norm itu mempunyai pengetahuan tentang peribahasa yang secukupnya. Selain itu, penyelidik juga menggunakan dua buah buku peribahasa dan mengambil beberapa contoh peribahasa yang serupa dengan data yang didapati untuk melihat maksud yang terkandung dalam buku tersebut serta dijadikan sebagai rujukan sahaja. Penyelidik mendapatkan segala data hasil daripada temu bual serta dua buah buku peribahasa Tamil pula digunakan sebagai rujukan. Segala data yang dirakam disimpan dengan rapi bagi menjaga kesahihan data tersebut. Reka bentuk penyelidikan ini seperti ditunjukkan dalam Jadual 1.

Jadual 1

Reka bentuk penyelidikan

\begin{tabular}{cccc}
\hline $\begin{array}{c}\text { Reka bentuk } \\
\text { kajian }\end{array}$ & $\begin{array}{c}\text { Kaedah } \\
\text { pengumpulan }\end{array}$ & Informan/ sampel & Jenis data \\
\hline & Temu bual & $\begin{array}{c}\text { Empat orang yang } \\
\text { beragama Hindu }\end{array}$ & Kualitatif \\
Deskriptif & Kepustakaan & - & - \\
\hline
\end{tabular}

Daripada sejumlah 25 data yang dikutip, sebanyak 6 peribahasa yang berkaitan imej rumput dibicarakan lanjut di sini. Semua contoh tersebut ditulis dalam bahasa Tamil dan diberikan trankripsi dalam tulisan rumi berserta maksud seperti ditunjukkan dalam Jadual 2.

Jadual 2

Senarai 6 peribahasaTamil yang mengandungi imej rumput

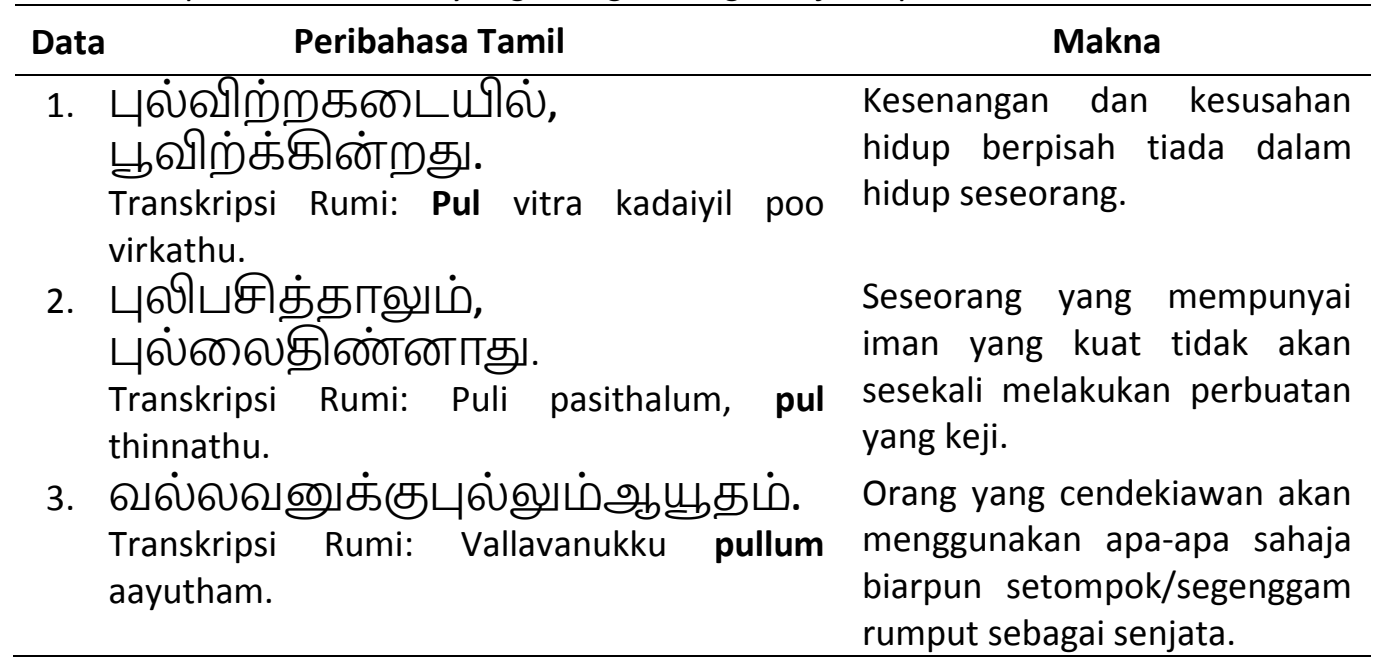


Jadual 2 (sambungan).

4. கலுவைக்குதெரியுமாகற்பூரவாசம். Seseorang individu tidak Transkripsi Rumi: Kaluthaikku theriyuma karpoora sebenarnya tahu akan vaasanai.

kelebihan, kemampuan serta keunikan sendiri sehingga dicungkil.

5. அருகம்புல்லும்பல்குத்தஉதவும். Benda yang dianggap Transkripsi Rumi: Arukumpullum aabathuku tidak berguna juga uthavum. mampu berguna pada waktu kecemasan.

6. கோரைபுல்குளத்தைகெடுக்கும். Oleh sebab kejahatan salah seorang anggota kumpulan atau masyarakat, maka orang lain juga mendapat nama yang buruk.

Analisis data dilakukan melalui beberapa peringkat. Penyelidik pada mulanya mengutip segala data yang diperlukan. Seterusnya, penyelidik membahagikan dahulu data yang dikutip melalui temu bual serta data yang didapati dalam buku peribahasa Tamil. Setelah itu, penyelidik menyenaraikan kesemua peribahasa tersebut dalam bentuk jadual dengan maksudnya sekali. Selepas itu, penyelidik melakukan penterjemahan data kerana segala data yang dikutip adalah dalam bahasa Tamil. Mengikut Mohd dan Hassan (2008), seseorang yang ingin menterjemah harus memenuhi empat syarat yang penting iaitu mengetahui sumber, mengetahui bahasa penerima, pengetahuan dalam bidang yang diterjemah serta mengetahui teori dan amalan terjemahan. Penyelidik mengunakan buku panduan menterjemah dan kamus Dewan edisi keempat sebagai rujukan untuk melakukan penterjemahan peribahasa tersebut. Penterjemahan itu mempunyai dua peringkat iaitu bermula pada peringkat penterjemahan terus (direct translation) dari bahasa Tamil kepada bahasa Melayu tanpa melihat aspek-aspek tatabahasa serta susunan perkataan. Setelah penterjemahan terus itu selesai, penyelidik menterjemahkan sekali lagi daripada bahasa Tamil kepada bahasa Melayu tetapi penterjemahan pada peringkat ini lebih menumpukan perhatian kepada terjemahan yang bersifat sistematik dan tersusun dari segi tatabahasa dan juga bersifat gramatis mengikut bahasa Melayu.

Setelah proses penterjemahan selesai sepenuhnya, penyelidik mula menganalisis data tersebut mengikut konsep semantik inkuisitif dan akal budi masyarakat India. Bukti-bukti yang diambil sewaktu temu bual digunakan untuk mengaitkan sebab mengapa masyarakat Tamil menggunakan imej tumbuhan seperti, rumput dalam peribahasa. Setiap satu peribahasa dikaitkan dengan pengaruh budaya, akal budi serta falsafah hidup masyarakat India. Di samping itu, ketika menganalisis data ini, penyelidik juga mengaitkannya dengan pemikiran orang India pada zaman dahulu sehingga boleh mencipta peribahasa-peribahasa yang 
bersifat memberi teladan serta pengajaran yang diingati sehingga ke hari ini. Makna implisit di sebalik setiap satu peribahasa dikaji melalui konsep semantik inkuisitif.

\section{Dapatan dan Perbincangan}

Peribahasa dikenali sebagai 'pazhamozhi' dalam bahasa Tamil. Menurut Parameswaran (2016), perkataan 'pazhamozhi' itu dapat dipisahkan kepada dua iaitu 'pazha' yang bermaksud keindahan bahasa yang diguna pakai sejak zaman dahulu dan perkataan 'mozhi' pula bermaksud bahasa. Beliau juga menyatakan bahasa orang dahulu lebih gemar menggunakan peribahasa atau 'pazhamozhi' itu untuk menyampaikan sesuatu hasrat tanpa menyinggung perasaan seseorang individu atau sekumpulan masyarakat. Hal ini adalah disebabkan masyarakat dahulu mementingkan kesopanan dan keakraban yang juga menjadi budaya masyarakat India sehingga kini. Kebanyakan peribahasa yang dicipta bersifat memberi pengajaran. Peribahasa Tamil merupakan hasil pengalaman orang-orang dahulu terutamanya masyarakat yang lahir di Tamilnadu dan Sri Lanka. Beliau juga menyatakan bahawa peribahasa Tamil muncul di negara kita melalui orang-orang Tamil yang datang ke Tanah Melayu sebagai pekerja dan kuli. Masyarakat yang datang ke negara kita membawa bersama tradisi, budaya, amalan, bahasa serta kepercayaan mereka. Jika dilihat dengan teliti penggunaan peribahasa merupakan amalan masyarakat India ketika dahulu. Oleh hal yang demikian, peribahasa tersebut juga mula digunakan secara meluas di negara kita. Jika dilihat dari perseptif informan kajian ini iaitu iaitu Pn Komathy (perbualan lisan, 2017), peribahasa dikatakan sebagai satu penggunaan yang menggunakan pelbagai perkataan yang menyinggung perasaan orang serta memperlihatkan keindahan bahasa tersebut.

\section{Analisis semantik inkuisitif dalam peribahasa Tamil}

analisis data peribahasa Tamil 1 - "Poovitra kadaiyil pul virkethu".

Jadual 3

Peribahasa Tamil iaitu "Poovitra kadaiyil pul virkethu" berserta makna mudah

\begin{tabular}{ll}
\hline \multicolumn{1}{c}{ Peribahasa Tamil } & \multicolumn{1}{c}{ Makna } \\
\hline Data 1: & Kesenangan dan kesusahan hidup berpisah \\
புல்விற்றகடையில், & tiada dalam hidup seseorang. \\
பூவிற்க்கின்றது. & \\
Transkripsi Rumi: Poovitra kadaiyil pul & \\
virkethu. & \\
\hline
\end{tabular}

'Poovitra kadaiyil pul virkerthu' bermaksud kedai yang menjual bunga dahulu, kini menjual rumput juga. Namun makna tersirat di sebalik peribahasa ini pula menceritakan bahawa kita sebagai manusia yang biasa akan menghadapi kesenangan serta kesusahan dalam hidup kita. Makna yang dikemukakan secara tersirat mempunyai kaitan dengan budaya, konteks penggunaan, pengalaman serta persekitaran, emosi, pendidikan dan pandangan tentang dunia (Subet, \& Daud, 
2018). Hal ini demikian kerana dalam sesebuah masyarakat sememangnya mempunyai suatu peraturan ataupun etika ketika berbahasa sama ada disebabkan oleh faktor kesopanan mahupun adat dan kepercayaan (Daud, Abd Wahid \& Gedat, 2017). Kita tidak dapat mengelakkan diri kita daripada kedua-dua perkara tersebut. Jika kita senang serta gembira hari ini, berkemungkinan esok kita menghadapi kesusahan dan berasa sedih. Mereka juga ingin menjelaskan bahawa kesenangan serta kesusahan ini tidak akan kekal selama-lamanya malah ia akan berubah dan tidak menentu.

Kenapa rumput (pul) digunakan serta kenapa dikaitkan dengan bunga (poo)?Rumput (pul) dikelasifikasikan sebagai satu tumbuhan yang tidak mempunyai sebarang kegunaan kepada masyarakat India. Oleh hal yang demikain, rumput (pul) selalunya dikaitkan dengan perkara yang tidak baik atau buruk. Dalam isu ini, rumput (pul) digunakan untuk menunjukkan kesusahan hidup. Masyarakat India ingin membuat perbandingan antara kehidupan rumput (pul) serta ciri-ciri rumput (pul) itu dengan kehidupan manusia. Jika dilihat dengan teliti, kebanyakan rumput (pul) mempunyai ciri-ciri yang serupa iaitu liang, lembut, mudah tercabut, jangka hayat yang sederhana, tidak kuat dan sebagainya. Kita sedia maklum bahawa masyarakat dahulu akan mencipta peribahasa dengan menggunakan alam sekeliling mereka. Oleh hal yang demikian, masyrakat India memilih rumput (pul) kerana ingin menyampaikan maklumat bahawa rumput (pul) sebenarnya tidak ada kegunaannya kepada kita kerana tidak mempunyai sebarang kebaikan. Bunga (poo) pula dikaitkan dengan perkara yang baik serta gembira kerana bunga (poo) selalunya cantik, wangi dan mempunyai pelbagai kegunaan. Antara contoh penggunaannya ialah, untuk tujuan sembayang, sebagai hiasan rumah, bunga melur pula diikat bersama rambut oleh kaum wanita untuk mewangikan rambut serta menarik kaum lelaki dan sebagainya. Menurut ketiga-tiga informan, kegunaan bunga ( $p o o$ ) ini selalunya untuk perkara yang positif sahaja. Namun bunga (poo) juga digunakan untuk upacara kematian namun bunga (poo) yang digunakan dalam upacara tersebut biasanya bunga yang tidak berwarna-warni dan tidak mengeluarkan kewangian. Oleh hal yang demikian, masyarakat India ingin mengaitkan benda yang dianggap positif iaitu bunga (poo) dan perkara yang dianggap negatif iaitu rumput (pul) yang tidak langsung berguna kepada masyarakat India. Perbandingan ini dilakukan melalui pengetahuan yang mendalam terhadap alam sekeliling mereka, falsafah iaitu pengetahuan tentang setiap pengertian yang digunakan dalam mencipta sesuatu peribahasa. Apabila kita melihat dari perspektif peribahasa ini, biasanya kedai yang menjual bunga (poo) tidak akan menjual rumput (pul) kerana rumput (pul) itu tidak berguna tetapi setelah sekian lama, kedai tersebut juga menjual rumput (pul) bermakna terdapatnya masalah atau kesusahan yang dialami oleh pemilik kedai tersebut sehingga benda yang tidak dijual selama ini terpaksa dijual. Melalui peribahasa ini, mereka ingin menyatakan bahawa seseorang yang hidup senang juga akan mendapat kesusahan dalam hidup kerana kesusahan dan kesenangan berpisah tiada dalam hidup kita. Jika dilihat dengan teiti sehingga kini, masyarakat India yang membuat perniagaan bunga tidak akan sesekali menjual rumput waimapun untuk hiasan dalam jambang bunga. Di samping itu, peribahasa ini jelas menunjukkan pemikiran orang India yang mempunyai satu falsafah serta pegangan hidup dalam isu-isu berkenaan kematian dan sebagainya. 
analisis data peribahasa Tamil 2 - "Puli pasithalum, pul thinnathu".

Jadual 4

Peribahasa Tamil iaitu "Puli pasithalum, pul thinnathu" berserta makna mudah

\begin{tabular}{ll}
\hline \multicolumn{1}{c}{ Peribahasa Tamil } & \multicolumn{1}{c}{ Makna } \\
\hline Data 2: & Seseorang yang mempunyai iman yang kuat \\
புலிபசித்தாலும், & tidak akan sesekali melakukan perbuatan \\
புல்லைதிண்னாது. & yang keji. \\
Transkripsi Rumi: Puli pasithalum, & \\
pul thinnathu. & \\
\hline
\end{tabular}

Peribahasa tamil 'puli pasithalum, pul thinnathu' bermaksud walaupun harimau itu lapar dan kebuluran, haiwan tersebut tidak akan sama sekali memakan rumput. Sebaliknya apabila melihat makna implisitnya, masyarakat India ingin menjelaskan bahawa seseorang yang mempunyai iman yang kuat serta jati diri yang tinggi, orang tersebut tidak akan sesekali melakukan sebarang perbuatan keji yang boleh memburukkan nama baik diri sendiri, keluarga serta negara.

Walau bagaimanapun, apabila dikaji dari segi semantik inkuisitif pula, terdapat beberapa sebab mengapa masyarakat India menggunakan rumput (pul) dalam peribahasa tersebut. Rumput (pul) ini merupakan sejenis tumbuhan menjadi makanan utama haiwan herbivor seperti lembu, kambing, kerbau dan sebagainya. Istilah herbivor bermakna haiwan yang hanya makan tumbuh-tumbuhan sahaja. Namun demikian kenapa harimau (puli) pula dikaitkan dengan rumput (pul)? Apabila melihat dari sudut sains, harimau (puli) diklasifikasikan dalam ketagori karnivor iaitu haiwan yang memakan daging binatang sahaja. Hal ini bersangkut-paut dengan tabiat pemakanan haiwan itu dengan sifatnya. Harimau disifatkan sebagai satu haiwan yang kuat, buas dan berbahaya. Kita mengakui hakikat bahawa harimau (puli) hanya memakan daging binatang lain sahaja dan tidak memakan tumbuhtumbuhan. Namun demikian, dalam peribahasa ini masyarakat India juga menjelaskan bahawa harimau (puli) yang lapar tidak akan sesekali memakan rumput (pul). Hal ini disebabkan mereka ingin menonjolkan perbezaan antara haiwan karnivor iaitu harimau (puli) dan rumput (pul) yang bukannya sasaran makanan haiwan tersebut. Mengikut falsafah hidup masyarakat rumput (pul) tidak mempunyai sebarang kegunaan atau kebaikan kepada seseorang. Bagaimanakah mereka tahu tentang kebaikan serta keburukan sesuatu tumbuhan itu? Jawapannya cukup mudah. Pada zaman dahulu kebanyakan masyarakat India merupakan golongan petani dan penternak. Oleh hal yang demikian, mereka mempunyai pengetahuan tentang setiap pengertian di sekeliling mereka. Jika dilihat dengan teliti, rumput (pul) itu hanya menjadi sumber pemakanan bagi haiwan herbivor dan omnivor sahaja. Oleh hal yang demikian, masyarakat India ingin menyesuaikan peribahasa tersebut dengan hidup manusia dalam alam realiti. Harimau (puli) digantikan dengan manusia dan rumput (pul) digantikan dengan kejahatan dalam 
alam nyata. Konklusinya, mereka ingin menyatakan bahawa orang yang bijak pandai tidak akan terlibat dalam apa-apa jua kancah gejala sosial yang mampu mencemarkan nama baik diri sendiri.

analisis data peribahasa Tamil 3 - "Vallavanukku pullum aayutham".

Jadual 5

Peribahasa Tamil iaitu "Vallavanukku pullum aayutham" berserta makna mudah

\begin{tabular}{ll}
\hline \multicolumn{1}{c}{ Peribahasa Tamil } & \multicolumn{1}{c}{ Makna } \\
\hline Data 3: & Orang yang cendekiawan akan \\
வல்லவனுக்குபுல்லும்ஆயூதம். & $\begin{array}{l}\text { menggunakan apa-apa sahaja biarpun } \\
\text { setompok/segenggam rumput sebagai } \\
\text { Transkripsi Rumi: Vallavanukku pullum } \\
\text { aayutham. }\end{array}$ \\
& senjata.
\end{tabular}

Peribahasa ini bermakna seseorang yang bijak pandai atau cendekiawan (vallavan) mampu menggunakan apa-apa sahaja termasuk rumput (pul) sebagai senjata ketika situasi kecemasan. Melalui peribahasa ini kita dapat melihat bahawa masyarakat India menekankan aspek pendidikan. Masyarakat India sememangnya golongan yang mementingkan pendidikan. Hal ini jelas dilihat melalui peribahasa tersebut. Mereka ingin mengatakan bahawa kita perlu bijak dan harus menjadi sebagai orang yang cendekiawan (valavan) kerana hanya melalui pendidikan sahaja seseorang itu mampu berfikir dan menggunakan akal fikiran untuk mencari jalan penyelesaian bagi sesuatu masalah. Jika seseorang itu tiada berpendidikan sudah tentu orang tersebut tidak mampu berfikir setanding dengan orang yang berpendidikan.

Masyarakat India memilih rumput ( $p u l)$ untuk dikaitkan dengan orang yang bijak pandai (valavan) kerana rumput (pul) dikelasifikasikan sebagai satu tumbuhan yang tidak mempunyai kegunaan yang tinggi di samping menjadi makanan kepada haiwan peliharaan mereka iaitu lembu dan kerbau. Dengan ini, mereka ingin menyatakan bahawa walaupun kita percaya rumput (pul) itu tidak banyak kegunaannya malah jika rumput (pul) itu dapat pada orang bijak pandai (valavan), orang tersebut mampu menggunakannya dalam sesuatu keadaan biarpun sebagai satu senjata untuk mencederakan musuh yang menyerang orang tersebut. Oleh hal yang demikian, sudah terang lagi bersuluh bahawa masyarakat India merupakan masyarakat yang mementingkan pendidikan di samping pertanian sebagai pekerjaan utama mereka.

analisis data peribahasa Tamil 4 - "Kaluthaikku theriyuma karpoora vaasanai".

Jadual 6

Peribahasa Tamil iaitu "Kaluthaikku theriyuma karpoora vaasanai" berserta makna mudah

Peribahasa Tamil Makna




\begin{tabular}{llcc}
\hline Data 4: & Seseorang individu tidak \\
கலுதைக்குதெரியுமாகற்பூரவாசம். & sebenarnya tahu akan \\
Transkripsi Rumi: Kaluthaikku theriyuma karpoora & kelebihan, kemampuan serta \\
vaasanai. & $\begin{array}{l}\text { keunikan sendiri sehingga } \\
\text { dicungkil. }\end{array}$
\end{tabular}

Makna harfiah bagi peribahasa ini ialah, menceritakan bahawa rumput kalu (kaluthaikku) sebenarnya tidak tahu akan kelebihannya iaitu dapat mengeluarkan bau yang wangi seperti kapur barus (karpoora). Jika dilihat dari segi akal budi masyarakat India, perkataan 'kalu' merupakan sejenis rumput yang memiliki suatu kewangian yang serupa seperti kapur barus dan digunakan untuk membuat tikar. Nama lain bagi 'kalu' ialah 'korai'. Menurut informan Saravanan a/l Paramesvaran (perbualan lisan, 2018), masyarakat pada zaman dahulu sememangnya aktif dalam penghasilan barang-barang kegunaan harian dengan menggunakan flora yang semula jadi. Hal ini disebabkan masyarakat India dahulu terlalu mementingkan aktiviti-aktiviti pertanian, perhutanan dan pemburuan. Aktiviti sebegini menjadikan mereka mengambil tahu akan setiap benda (flora dan fauna) yang mereka jumpa serta menggunakan benda itu sebaik yang mungkin. Walau bagaimanapun, apabila melihat peribahasa ini, masyarakat India memilih rumput 'kalu' ini kerana mempunyai pelbagai keunikan serta kelebihan. Tikar yang diperbuat daripada rumput 'kalu' tersebut hanya digunakan oleh golongan yang berada sahaja dan dijual dengan harga yang agak mahal. Orang biasa tidak akan membeli tikar tersebut kerana tidak sebenarnya tahu akan kebaikannya dan disebabkan masalah kewangan. Tikar yang diperbuat daripada rumput itu sebenarnya mempunyai pelbagai kelebihan. Antaranya ialah rumput itu akan mengeluarkan kewangian seperti kapur barus. Malah serangga perosak juga tidak akan mendekati tikar tersebut kerana kewangian kapur barus itu dan tikar tersebut juga diguna pakai untuk tujuan 'ayurvedic' iaitu untuk perubatan tradisional. Namun adakah seseorang itu tahu akan kelebihan dan keunikan itu sendiri. Jawapannya sudah semestinya tidak sehingga seseorang itu menggunakannya.

Oleh hal yang demikian masyarakat mengaitkan rumput itu dengan manusia. Seseorang itu tidak akan tahu bakat, kelebihan, dan keunikkan mereka sehingga dicungkil bakat tersebut sama seperti penggunaan rumput 'kalu' mengeluarkan kewangian itu tetapi seseorang itu akan hanya mengetahuinya setelah digunakan sahaja. Masyarakat India menggunakan imej tumbuhan ini kerana pada zaman dahulu masyarakat akan mencipta peribahasa dengan unsur-unsur di sekelilingnya. Namun demikian kebanyakan masyarakat India sendiri tidak sebenarnya tahu akan makna yang ingin disampaikan melalui peribahasa tersebut pada era robotik ini. Kajian ini mendapati bahawa masyarakat India sendiri menganggap perkataan 'kaluthai' itu sebagai keldai dan bukannya sejenis rumput kerana pada masa kini rumput tersebut jarang digunakan malah tidak terdapat di negara kita. Di samping itu, kajian ini juga mendapati bahawa, hanya orang tua dan orang yang berpendidikan Tamil sahaja yang benar-benar tahu akan maksud yang disampaikan kerana setiap peribahasa yang cipta mempunyai kaitan dengan budaya, akal budi, pemikiran serta falsafah hidup masyarakat India. 
analisis data peribahasa Tamil 5 - "Arukumpullum aabathuku uthavum".

Jadual 7

Peribahasa Tamil iaitu "Arukumpullum aabathuku uthavum" berserta makna mudah

\begin{tabular}{ll}
\multicolumn{1}{c}{ Peribahasa Tamil } & \multicolumn{2}{c}{ Makna } \\
\hline Data 5: & Benda yang dianggap tidak \\
அருகம்புல்லும்பல்குத்தஉதவும். & $\begin{array}{l}\text { berguna juga mampu berguna } \\
\text { pada waktu kecemasan. } \\
\text { Transkripsi Rumi: Arukumpullum aabathuku } \\
\text { uthavum. }\end{array}$ \\
\hline
\end{tabular}

Peribahasa 'arukumpullum aabathuku ithavum' bermakna rumput bermuda (arukumpul) yang juga dikenali sebagai wheat grass pun akan berguna sewaktu kecemasan manakala apabila melihat makna tersirat peribahasa ini, ia menceritakan bahawa benda yang dianggap tidak akan berguna lagi juga mampu berguna kepada kita sewaktu kecemasan.

Kenapa rumput bermuda (arukumpul) digunakan? Kenapa rumput jenis yang berbeza tidak digunakan? Imej tumbuhan ini diguna pakai kerana kegunaannya. Rumput bermuda (arukumpul) ini dikatakan mempunyai keistimewaan iaitu dapat menghilangkan rasa panas dalam badan kita. Menurut Gaunder (2016), terdapat satu cerita mitos yang menyebabkan terciptanya peribahasa ini. Dalam cerita mitos tersebut, terdapat satu raksasa yang mempunyai kehangatan atau kepanasan yang tidak terhingga sehingga dewa api (agni dewa) tidak dapat mendekatinya. Oleh disebabkan tiada sesiapa yang mampu mendekatinya, raksasa tersebut melakukan kekacauan di semua tempat. Pada suatu hari, dewa yang memiliki kepala gajah menelan raksasa tersebut. Setelah ditelan, dewa tersebut juga tidak dapat menahan kehangatan raksasa yang berada di dalam perutnya. Pada ketika itulah, pendeta yang berada di situ mengumpul rumput bermuda (arukumpul) dan mengikatnya mengelilingi perut dewa gajah tersebut. Setelah itulah, kehangatan itu mula berkurang. Melalui cerita tersebut, kita mendapat tahu bahawa rumput bermuda (arukumpul) pun boleh berguna sewaktu kecemasan. Masyarakat India dikatakan mencipta peribahasa ini berdasarkan cerita mitos ini kerana masyarakat dahulu biasanya akan mencipta peribahasa yang mempunyai ciri-ciri budaya mereka. Oleh sebab itulah, rumput bermuda (arukumpul) yang dapat menghilangkan rasa panas itu mereka gunakan dalam ciptaan peribahasa ini. Malah rumput bermuda (arukumpul) sehingga kini digunakan dalam bentuk minuman di negara kita untuk tujuan menghilangan rasa panas dalam badan. Di samping itu, mereka memilih rumput (pul) kerana kebanyakan masyarakat India merupakan golongan petani. Oleh hal yang demikian mereka memilih perkara yang berdekatan dengan mereka untuk dijadikan peribahasa kerana cara hidup dan budaya memainkan peranan yang amat kuat dalam penciptaan setiap peribahasa. 
analisis data peribahasa Tamil 6 - "Koraipul kulathai kedekum".

Jadual 8

Peribahasa Tamil iaitu “Koraipul kulathai kedekum" berserta makna mudah

\begin{tabular}{ll}
\hline \multicolumn{1}{c}{ Peribahasa Tamil } & \multicolumn{1}{c}{ Makna } \\
\hline Data 6: & $\begin{array}{l}\text { Oleh sebab kejahatan salah } \\
\text { கோரைபுல்குளத்தைகெடுக்கும். }\end{array}$ \\
seorang anggota kumpulan atau \\
Transkripsi Rumi: Koraipul kulathai kedekum. & $\begin{array}{l}\text { masyarakat, maka orang lain juga } \\
\text { mendapat nama yang buruk. }\end{array}$
\end{tabular}

Perkataan koraipul bermaksud sejenis rumput. Seperti yang dijelaskan dalam analisis di atas, rumput korai (korai pul) mempunyai pelbagai kegunaannya. Namun demikian, yang dimaksudkan dengan peribahasa 'koraipul kulathai kedekum' ialah setompok rumput korai (korai pul) mampu merosakkan pemandangan keseluruhan kolam tersebut. Maksud implisit sebalik peribahasa ini ialah disebabkan kesalahan, kejahatan dan dilakukan oleh hanya seorang anggota kumpulan atau masyarakat, maka orang lain juga akan mendapat nama yang buruk disebabkan perbuatan itu. Terdapat juga contoh peribahasa Melayu yang mendukung makna yang sama seperti peribahasa ini. Tamsilnya, sebab nila setitik, rosak susu sebelanga, seekor kerbau membawa lumpur semuanya terpalit dan ibarat telur sesangkak, pecah sebiji, pecah semua.

Rumput korai (koraipul) ini digunakan kerana masyarakat yang mencipta peribahasa dikatakan akan memilih unsur-unsur yang berada di sekeliling mereka. Hal ini juga berkait rapat dengan pekerjaan mereka. Kebanyakan masyarakat India dahulu merupakan petani yang bekerja di sawah padi. Oleh hal itu, mereka menggunakan rumput (koraipul) sebagai contoh dalam peribahasa tersebut. Contohnya apabila mereka melihat tumbuhnya rumput (koraipul) di tengah-tengah kawasan tanaman padi, mereka menggangap rumput (koraipul) tersebut merosakkan keseluruhan pemandangan di sekitar kawasan tersebut. Jika di biarkan rumput (koraipul) itu akan tumbuh lebih banyak. Oleh hal yang demikian mereka akan mencantas rumput (koraipul) yang tumbuh di kawasan tanaman padi. Melalui peribahasa ini, masyarakat India ingin mengaitkan falsafah kehidupan manusia dengan rumput (koraipul) tersebut. Apabila seorang ahli keluarga melakukan kesalahan, keseluruhan keluarga terpaksa menanggung malu sama seperti dalam peribahasa iaitu apabila tumbuhnya hanya satu rumput (koraipul) musnah pemandangan keseluruhan kawasan.

\section{Kesimpulan}

Akhirulkalam, kajian ini membuktikan bahawa setiap peribahasa yang dicipta oleh masyarakat India mempunyai makna implisit di sebalik penciptaan tersebut di samping mempunyai ciri-ciri budaya yang mempengaruhi penciptaan peribahasa tersebut. Ciri-ciri budaya tersebut menyebabkan tercipta peribahasa untuk dijadikan suri teladan kepada masyarakat serta menjadi panduan dalam hidup. Penggunaan 
ungkapan yang berkias seperti peribahasa ini juga mampu mewujudkan suasana yang harmoni serta saling hormat-menghormati sesama manusia dan juga terhadap alam sekitar yang sinonim dalam kehidupan sesebuah masyarakat (Daud, Abd Wahid \& Gedat, 2018). Melalui analisis yang telah dilakukan, ketiga-tiga objektif kajian ini telah dicapai sepenuhnya. Kajian ini juga membuktikan bahawa setiap peribahasa yang digunakan mempunyai makna implisit atau makna di sebalik peribahasa tersebut yang begitu mendalam sifatnya. Jika dilihat dengan teliti, terdapat pelbagai sebab di sebalik penggunaan imej rumput dalam setiap peribahasa yang dikaji. Di samping itu, kajian ini diharap agar menjadi satu instrumen atau alat untuk menyemarakkan lagi semangat mengenali budaya sesuatu kaum terutamanya kaum India di negara kita di samping menghidupkan semula penggunaaan peribahasa dengan lebih meluas agar menjadi satu tabiat ketika berkomunikasi. Hal ini demikian kerana, melalui peribahasa seseorang dapat mengutarakan pendapat, nasihat, kritikan tanpa menyinggung perasaan seseorang. Malah penggunaan peribahasa secara meluas juga dapat membantu seseorang untuk lebih menjiwai kepentingan peribahasa tersebut yang mampu menjadi satu petunjuk jalan ke arah perkaraperkara yang positif serta menghindarkan perkara yang negatif. Kajian ini juga diharap akan menjadi satu rujukan kepada penyelidik-penyelidik lain yang melakukan kajian terhadap peribahasa.

\section{Rujukan}

Abdullah, H. (1997). Canai budi. Kuala Lumpur: Dewan Bahasa dan Pustaka.

Ahmad, Z. A. (Za'ba), (1965). Ilmu mengarang Melayu. Kuala Lumpur, Malaysia: Dewan Bahasa dan Pustaka.

Ciardelli, I., Groenendijk, J., \& Roelofsen, F. (2012). Inquisitive semantics. Oxford University Press.

Daud, M. Z. (2017). Slanga kedai kopi: Satu analisis semantik inkuisitif (Tesis sarjana muda tidak diterbitkan). Universiti Malaysia Sarawak, Malaysia.

Daud, M. Z. (2018a). Domain rezeki dalam peribahasa Melayu berorientasikan Aves melalui perspektif semantik inkuisitif. MALTESAS Multi-Disciplinary Research Journal (MIRJO), 3(1), 19-28.

Daud, M. Z. (2018b). Gallus gallus domesticus dan Paradoxurus hermaphroditus dalam peribahasa Melayu: Analisis semantik inkuisitif. Sains Humanika, 10(2), 41-51.

Daud, M. Z., Abd Wahid, M. S. N., \& Gedat, R. (2017). Eufemisme dalam bahasa Iban: Satu kajian kes di Kampung Lebor, Serian, Sarawak. Borneo Research Journal, 11(1), 87-105.

Daud, M. Z., Abd Wahid, M. S. N., \& Gedat, R. (2018). Penggunaan eufemisme dalam kalangan penutur Iban. International Journal of Language Education and Applied Linguistics (IJLEAL), 8.

Daud, M.Z., \& Subet, M. F. (2018). Ayam (gallus gallus domesticus) dalam peribahasa Melayu: Analisis semantik inkuisitif. Jurnal Kemanusiaan, 16(1).

Farndon, J. (2011). 1000 Fakta tentang tumbuhan. Institut Terjemahan Negara Malaysia. Kuala Lumpur, Malaysia.

Gaunder, A. (2016). Routledge handbook of Japanese politics. London: Routledge. 
Hamzah, Z. A. Z., \& Mat Hassan, A. F. (2011). Peribahasa Melayu: Penelitian makna dan nilai. Serdang, Malaysia: Penerbit Universiti Putra Malaysia (UPM).

Jabatan Perangkaan Malaysia. (2013). Siaran akhbar akaun negara perangkaan stok modal 2005-2012. Diperolehi daripada https://www.dosm.gov.my/v1/2012/ Stok_Modal2005-2012.pdf

Jalaluddin, N. H. (2014a). Semantik dan akal budi Melayu. Selangor, Malaysia: Universiti Kebangsaan Malaysia.

Jalaluddin, N. H. (2014b). Pemugaran penyelidikan untuk pemerkasaan bahasa. Diperolehi daripada Institut Alam dan Tamadun Melayu, Universiti Kebangsaan Malaysia website: http://eseminar.dbp.gov.my/ceramahnj/ kertas_kerja_norhashimah_jalaluddin.

Jalaluddin, N. H. (2015). Peribahasa 'Parasit' dan akal budi Melayu: Analisis semantik inkuisitif. In Seminar Bahasa dan Sastera 2015 (pp. 281-293). Bangi: Pusat Pengajian Bahasa dan Linguistik, Universiti Kebangsaan Malaysia.Kasdan, J., \& Jalaluddin, N. H. (2015). Unsur asam dan akal budi Melayu: Analisis semantik inkuisitif. In Seminar Meja Bulat: Simpulan Bahasa dan Kognitif Penutur (pp. 1-20). Kuala Lumpur: Institut Alam dan Tamadun Melayu (ATMA), Universiti Kebangsaan Malaysia.

Kasdan, J., Jalaluddin, N. H., \& Wan Ismail, W. N. (2016). Ikan (Pisces) dalam peribahasa Melayu: Analisis semantik inkuisitif. International Journal of the Malay World and Civilisation (Iman), 4(1), 31-41.

Mohd, A., \& Hassan, A. (2008). Teori dan teknik terjemahan. PTS Publications and Distributors.

Murthy, T. (2017). Imej tumbuhan dalam peribahasa Tamil: Suatu kajian semantik inkuisitif. (Tesis sarjana muda tidak diterbitkan). Universiti Malaysia Sarawak, Malaysia.

Nayak, S. (2002). Language of advertisements in Tamil mass media. Journal Language of India, 2(3), 1-92.

Omar, A. H. (1993). Bahasa dan alam pemikiran Melayu. Kuala Lumpur, Malaysia. Dewan Bahasa dan Pustaka.

Parameswaran, G. (2016). Languages and the Tamil terms. Scribd Publisher.

Ragavan, R., \& Salleh, C. I. H. (2015). Peribahasa Melayu dan peribahasa Tamil dari aspek sosial. Journal of Business and Social Development 3(1), 66-75.

Sapir, E. (1921). Language: An introduction to the study of speech. London, UK: Harcount Brace Jovanovich Publishers.

Subet, M. F., \& Daud, M. Z. (2018). Makna denotatif dan konotatif dalam slanga pelacur. MALTESAS Multi-Disciplinary Research Journal (MIRJO), 3(1), 29-43.

Yokammal, M. (2008). Bahasa Iklan dalam akhbar Tamil Malaysia: Satu kajian deskriptif. (Tesis sarjana tidak diterbitkan) Universiti Malaya, Kuala Lumpur, Malaysia.

Wan Mansor, N.A., \& Jalaluddin, N. H. (2015). Deria rasa dalam kiasan Melayu: Analisis semantik inkuisitif. Journal Pertanika Mahawangsa, 2(1), 1-16.

Wan Mansor, N.A., \& Jalaluddin, N. H. (2016). Makna implisit bahasa kiasan Melayu: Mempertalikan komunikasi, kognisi dan semantik. Jurnal Komunikasi, 32(1), 189-206. 
Zahid, I. (1998). Peribahasa Melayu: Satu klasifikasi yang tiada penentu. Jurnal Dewan Bahasa, 42(11), 979-984.

Zakaria, S., \& Jalaluddin N. H. (2016). Konsep ruang dalam Cik Tunggal: Analisis semantik inkuisitif. Gema: Online Journal of Language Studies, 16(3), 187204. 